\title{
p-ISSN 2302-0970 \\ e-ISSN 2723-0201 \\ TINGKAT PARTISIPASI PEREMPUAN DALAM PENYELENGGARAAN PEMERINTAHAN DESA BULUCENRANA KECAMATAN PITU RIAWA KABUPATEN SIDENRENG RAPPANG
}

\author{
Basmiati Jufri \\ Fakultas IImu Sosial dan IImu Politik, Universitas Muhammadiyah Sidenreng Rappang \\ basmiatij43152080.1b@gmail.com
}

\begin{abstract}
Abstrak
Penelitian ini bertujuan untuk mengetahui tingkat partisipasi perempuan dalam penyelenggaraan pemerintahan Desa dan faktor-faktor yang memengaruhi tingkat partisipasi perempuan dalam penyelenggaraan pemerintahan Desa Bulucenrana. Populasi penelitian ini adalah $1.231 \mathrm{KK}$ dan sampel sebanyak 92 KK. Teknik penarikan sampel yang digunakan yaitu Purpossive Sampling. Tipe penelitian ini adalah deskriptif kuantitatif. Teknik pengumpulan data adalah observasi, wawancara, penelitian pustaka dan kuesioner. Teknik analisis data menggunakan statistik dengan bantuan SPSS v.16. Hasil penelitian menunjukkan bahwa partisipasi perempuan $56 \%$ kurang baik terdiri dari partisipasi uang 59\%, partisipasi harta benda 59\%, partisipasi tenaga $56 \%$, partisipasi keterampilan $49 \%$, partisipasi buah pikiran $58 \%$, dan juga partisipasi sosial $57 \%$. Penyelenggaraan Pemerintahan Desa $54 \%$ kurang baik terdiri dari pelayanan (service) 61\%, pemberdayaan (empowerment) $50 \%$, dan pembangunan (development) 52\%. Berdasarkan SPSS v.16 dengan menggunakan rumus regresi maka aspek ekonomi $22 \%$, aspek sosial budaya $41 \%$, aspek geografi wilayah $81 \%$ memengaruhi tingkat partisipasi perempuan dalam penyelenggaraan Pemerintahan Desa Bulucenrana.
\end{abstract}

Kata kunci : Partisipasi Perempuan dan Penyelenggaraan Pemerintahan Desa

\begin{abstract}
This study aims to determine the level of women's participation in the administration of village governance and the factors that influence the level of women's participation in the administration of the village of Bulucenrana. The population of this study was 1,231 families and a sample of 92 households. The sampling technique used is Purpossive Sampling. This type of research is quantitative descriptive. Data collection techniques are observation, interviews, library research and questionnaires. Data analysis techniques use statistics with helped SPSS v.16. The results showed that the participation of women $56 \%$ was not good consisting of money participation 59\%, participation of property $59 \%$, participation of personnel $56 \%$, participation of skills $49 \%$, participation of ideas 58\%, and also social participation $57 \%$. The implementation of Village Government $54 \%$ is not good consisting of services $61 \%$, empowerment $50 \%$, and development $52 \%$. Based on SPSS v.16 using the regression formula, the economic aspects of $22 \%$, sociocultural aspects $41 \%$, geographic aspects of the region $81 \%$ affect the level of women's participation in the administration of the Village Government of Bulucenrana.
\end{abstract}

Keywords: Women's Participation and Implementation of Village Government 


\section{A. PENDAHULUAN}

Undang-Undang Dasar 1945 pasal 27 menjamin kesamaan hak bagi seluruh warga negara dihadapan hukum, baik laki-laki ataupun perempuan. Hal-hal tersebut jelas sangat menghargai peran perempuan pada masa silam dan mengantisipasi pada masa yang akan datang, dengan tidak ada satu kata pun yang bersifat deskriminatif terhadap perempuan. Konstitusi ini dengan tegas menyatakan persamaan hak dan kewajiban bagi setiap warga negara baik laki-laki ataupun perempuan, baik di kota maupun di pedesaan sekalipun.

Secara de facto, menunjukkan bahwa para kaum perempuan mengalami ketinggalan atau ketidakberuntungan lebih banyak dibandingkan dengan laki-laki. Terutama di daerah pedalaman alias pedesaan. Akibatnya, banyak orang tua yang menikahkan anak perempuannya di usia muda. Objektif ini tidak lain disebabkan oleh norma sosial dan nilai sosial budaya yang masih berlaku di masyarakat, seperti sistem kekerabatan patrilineal. Merupakan salah satu faktor yang secara relatif cenderung mempengaruhi status dan peranan perempuan menjadi lebih rendah dibandingkan laki-laki.

Rendahnya apresiasi perempuan terhadap hak-hak hidupnya merupakan suatu hal yang menyalahi kodratnya sebagai manusia. Sebagaimana tercantum dalam kertas kebijakan (policy brief) yang dikeluarkan oleh Kementerian Perencanaan Pembangunan atau Badan Perencanaan Pembangunan Nasional bersama dengan Kementerian Pemberdayaan Perempuan dan Perlindungan Anak Nomor 75844 yang berbunyi sebagai berikut "Kertas kebijakan 1, Pengarus-utamaan Gender diadopsi sejak penerbitan Instruksi Presiden Nomor 9 Tahun 2000. Intruksi Presiden Nomor 3 Tahun 2010 dan beberapa regulasi lainnya dari Kementerian mengenai pengarus-utamaan gender mengatur lebih jauh upaya-upaya untuk menuju pembangunan yang berkeadilan dan inklusif. Munculnya peraturan-peraturan yang tidak ramah perempuan di tingkat daerah menandai pentingnya penegakan hukum dan kerangka kebijakan pengarus-utamaan gender, koordinasi diantara Kementerian Nasional dan institusi publik diberbagai tingkat, serta replikasi praktek-praktek yang baik".
Indonesia mengalami kemajuan dalam pengurangan kesenjangan gender dibeberapa area kunci di endowment (kesehatan dan pendidikan), kesempatan, voice dan agency, serta perangkat hukum yang diperlukan untuk pengarus-utamaan gender dalam pembangunan, termasuk juga suara perempuan dalam politik dan pengambilan keputusan di Indonesia. Representasi perempuan di Parlemen yaitu Dewan Perwakilan Rakyat (DPR), meningkat dari $11 \%$ pada tahun 2004 sampai 2009, meningkat lagi pada tahun 2009 sampai 2014 menjadi $18 \%$, meskipun representasi tetap lebih rendah dari $30 \%$ yang diharapkan (Oktavia, 2018:2-3).

Proses pemberdayaan masyarakat diarahkan pada pengembangan sumber daya manusia (di pedesaan). Pemberdayaan tidak hanya dilakukan kepada laki-laki saja, perempuan pun sangat baik untuk diberdayakan. Ibarat kehidupan rumah tangga, perempuan adalah jantung rumah, jika jantung rumah mengalami kendala maka akan berdampak pada kelangsungan rumah tangga. Begitu pula pada negara, perempuan memiliki peran yang sangat penting dalam penyelenggaraan pemerintahan, jika perempuan tidak dapat diberdayakan dengan sebaik-baiknya, maka negara tidak dapat mengikut perkembangan zaman.

Untuk mewujudkan landasan Negara Kesatuan Republik Indonesia yaitu Pancasila, sila nomor 5 yaitu berbunyi "keadilan sosial bagi seluruh rakyat Indonesia", yang dimaknai sebagai adanya persamaan kesempatan untuk seluruh rakyat didalam berbagai bidang termasuk politik dan pemerintahan di Indonesia. Maka dibentuklah pemerintahan daerah untuk membantu pemerintah pusat menyelenggarakan urusan pemerintahan yang berlandaskan UndangUndang Nomor 23 Tahun 2014, "Pemerintahan Daerah adalah penyelenggaraan urusan pemerintahan oleh pemerintah daerah dan dewan perwakilan rakyat daerah menurut asas otonomi dan tugas pembantuan dengan prinsip otonomi seluas-luasnya dalam sistem dan prinsip Negara Kesatuan Republik Indonesia sebagaimana dimaksud dalam UndangUndang Dasar Negara Republik Indonesia". Seperti yang tercantum pada UndangUndang Nomor 6 Tahun 2014 tentang Pemerintahan Desa, yang menyatakan 
bahwa Desa adalah kesatuan masyarakat hukum yang memiliki batas wilayah yang berwenang untuk mengatur dan mengurus urusan pemerintahan, kepentingan masyarakat setempat berdasarkan prakarsa masyarakat, hak asal usul, dan/atau hak tradisional yang diakui dan dihormati dalam sistem pemerintahan Negara Kesatuan Republik Indonesia.

Desa Bulucenrana merupakan salah satu dari dua belas desa/kelurahan yang ada di Kecamatan Pitu Riawa Kabupaten Sidenreng Rappang. Berdasarkan data Laporan Pertanggung Jawaban, Desa Bulucenrana memiliki jumlah penduduk 5.500 jiwa (LPPD Desa Bulucenrana 2018). 2.791 jiwa berjenis kelamin perempuan dan 2.709 jiwa berjenis kelamin laki-laki. Jika dilihat dari presentasi jumlah penduduk, maka perempuan dominan lebih banyak dibandingkan laki-laki. Namun berdasarkan hasil pengamatan awal peneliti pada bulan Desember 2018,

1. Menunjukkan bahwa tingkat partisipasi perempuan dalam penyelenggaraan pemerintahan desa masih sangat rendah. Sebagai contoh, pada kegiatan Musrenbangdes, keikutsertaan perempuan sangat rendah, perbandingan partisipasi perempuan belum dapat menyeimbangi partisipasi kelompok lakilaki yaitu 1:9 (dapat dilihat pada lampiran ke-3), padahal dalam kegiatan Musrenbangdes perempuan dapat memberikan masukan mengenai kegiatan pemberdayaan perempuan sehingga dapat diimplementasikan dalam kehidupan sehari-hari, contohnya dapat membantu menambah penghasilan dalam rumah tangga sehingga perempuan memiliki kegiatan yang bermanfaat.

2. Kemudian, jika diundang dalam kegiatan sosialisasi seperti sosialisasi kewirausahaan, penyuluhan pertanian atau peternakan, hanya sekian persen yang hadir. Padahal meskipun kegiatan penyuluhan pertanian atau peternakan diwajibkan untuk laki-laki, akan tetapi perempuan juga tidak ada salahnya jika ikut berpartisipasi, karena dapat menjadi bekal atau tambahan ilmu bagi perempuan untuk bercocok tanam atau beternak. Perempuan tidak ada salahnya jika mengetahui dan menerapkan pekerjaan yang dikerjakan laki-laki, karena jika suatu saat seorang perempuan atau ibu rumah tangga diberikan ujian dalam rumah tangga seperti misalnya kepala keluarga meninggal sehingga tugas bapak menafkahi keluarga berpindah tangan kepada ibu. Untuk itu, jika ibu sudah memiliki bekal dibidang pertanian atau peternakan, dibidang kewirausahaan seperti pembuatan kue, membentuk salon kecantikan, menjahit busana, dan seterusnya, maka ibu akan tetap mampu menafkahi keluarga, itulah manfaat perempuan dibekali ilmu tersebut.

3. Dalam jangka panjang, pemberdayaan perempuan dapat menjadi tolak ukur kesejahteraan desa. Semakin berdaya kelompok perempuan, maka semakin maju dan sejahtera kondisi desa. Wanita, baik sebagai warga negara maupun sebagai sumber insani bagi pembangunan mempunyai hak, kewajiban, dan kesempatan yang sama dengan pria di segala bidang kehidupan bangsa dan dalam segenap kegiatan pembangunan. Sehubungan dengan itu, kedudukannya dalam masyarakat dan peranannya dalam pembangunan perlu terus ditingkatkan serta diarahkan sehingga dapat meningkatkan pertisipasinya dan memberikan sumbangan yang sebesarbesarnya bagi pembangunan bangsa sesuai dengan kodrat, harkat, dan martabatnya (Rini, 2004:397)

Berdasarkan uraian permasalahan di atas, maka peneliti tertarik meneliti tentang "Tingkat Partisipasi Perempuan dalam Penyelenggaraan Pemerintahan Desa Bulucenrana Kecamatan Pitu Riawa Kabupaten Sidenreng Rappang" dengan tujuan untuk mengetahui tingkat partisipasi perempuan dalam penyelenggaraan Pemerintahan Desa dan untuk mengetahui faktor-faktor yang memengaruhi tingkat partisipasi perempuan dalam penyelenggaraan pemerintahan Desa Bulucenrana.

Menurut Davis dan Newstrom (Remiswal, 2013:29) partisipasi adalah keterlibatan mental dan emosional orangorang dalam situasi kelompok yang mendorong mereka memberikan kontribusi pada tujuan kelompok dan berbagai tanggung jawab untuk mencapainya. Cary dalam Remiswal (2013:29), berpendapat bahwa partisipasi merupakan kebersamaan atau saling memberikan sumbangan untuk kepentingan dan masalah-masalah bersama 
yang tumbuh dari kepentingan dan perhatian individu warga masyarakat itu sendiri.

Menurut Yeung dan McGee (Remiswal, 2013:29) partisipasi menggambarkan peran serta seseorang atau kelompok orang dalam suatu kegiatan, sehingga partisipasi merupakan tindakan ambil bagian dalam suatu kegiatan kepentingan bersama. Partisipasi berkenaan dengan kesiapan, kesetujuan, aktifitas dan tujuan secara pasti.

Menurut Ouchi yang dikutip Remiswal (2013:29), terdapat perbedaan dimensi dan fase dalam partisipasi, misalnya partisipasi dalam identifikasi masalah, partisipasi dalam pengumpulan informasi dan diskusi kelompok tentang kebaikan dan kekurangan bergabung dalam suatu kegiatan, partisipasi dalam peran perencaan atau formulasi kegiatan, partisipasi dalam mobilisasi sumberdaya, partisipasi dalam implementasi, partisipasi dalam pembagian keuntungan, atau partisipasi dalam pemantauan dan evaluasi kegiatan. Peneliti menyimpulkan bahwa partisipasi merupakan kesediaan atau kesiapan seseorang baik jiwa maupun raganya dalam suatu hal, yang dinilai bermanfaat untuk dirinya sendiri maupun kelompoknya. Faktor-faktor yang memengaruhi partisipasi, dikelompokkan dalam tiga aspek yaitu sebagai berikut:

1. Aspek ekonomi

Pada tingkat lokal, karakteristik wilayah perdesaan yang ditinjau dari aspek ekonomi dapat dilihat dari tingkat kesejahteraan dan mayoritas pekerjaan penduduknya.

2. Aspek sosial budaya

Perbedaan karakteristik suatu wilayah secara mudah dapat diidentifikasikan dari sosial budaya yang berkembang pada masyarakat setempat.

3. Aspek geografi wilayah

Aspek geografi suatu daerah yang dipertimbangkan dalam hubungannya dengan tingkat partisipasi masyarakat meliputi jarak desa dengan pusat kota, serta sumber daya yang dimilikinya. Pada kasus dimana letak geografis wilayah suatu desa jauh dari kota maka keadaan yang biasa dijumpai minimnya perhatian dalam pembangunan. Keberadaan geografis desa yang didalamnya menyangkut sumber daya alam yang dimiliki, telah menjadikan suatu wilayah memiliki potensi yang lebih kompetitif dibandingkan dengan wilayah lainnya secara ekonomi. (Kogoya, dkk, 2015:6)

Partisipasi perempuan digunakan teori dari Hamijoyo (Hirdayanti, 2018:11) mengemukakan 6 bentuk partisipasi, sebagai berikut:

a. Partisipasi uang adalah bentuk partisipasi untuk memperlancar usaha-usaha bagi pencapaian kebutuhan masyarakat yang memerlukan bantuan.

b. Partisipasi harta benda adalah partisipasi dalam bentuk menyumbang harta benda, biasanya berupa alat-alat kerja atau perkakas.

c. Partisipasi tenaga adalah partisipasi yang diberikan dalam bentuk tenaga untuk pelaksanaan usaha-usaha yang dapat menunjang keberhasilan suatu program.

d. Partisipasi keterampilan, yaitu memberikan dorongan melalui keterampilan yang dimilikinya kepada anggota masyarakat lain yang membutuhkannya. Dengan maksud agar orang tersebut dapat melakukan kegiatan yang dapat meningkatkan kesejahteraan sosialnya.

e. Partisipasi buah pikiran adalah partisipasi berupa sumbangan berupa ide, pendapat atau buah pikiran konstruktif, baik untuk menyusun program maupun untuk memperlancar pelaksanaan program dan juga untuk mewujudkannya dengan memberikan pengalaman dan pengetahuan guna mengembangkan kegiatan yang diikutinya.

f. Partisipasi sosial, Partisipasi jenis ini diberikan oleh partisipan sebagai tanda paguyuban. Misalnya arisan, menghadiri kematian, dan lainnya dan dapat juga sumbangan perhatian atau tanda kedekatan dalam rangka memotivasi orang lain untuk berpartisipasi.

Undang-Undang Nomor 6 Tahun 2014 tentang Pemerintahan Daerah, Desa atau yang disebut dengan nama lain, selanjutnya disebut desa, adalah kesatuan masyarakat hukum yang memiliki batas-batas wilayah yang berwenang untuk mengatur dan mengurus kepentingan masyarakat setempat, berdasarkan asal-usul dan adat istiadat setempat yang diakui dan dihormati dalam sistem Pemerintahan Negara Kesatuan Republik Indonesia.

Pengertian desa dari sudut pandang sosial budaya dapat diartikan sebagai komunitas dalam kesatuan geografis tertentu 
dan antar mereka saling mengenal dengan baik dengan corak kehidupan yang relative homogen dan banyak bergantung secara langsung dengan alam. Oleh karena itu, desa diasosiasikan sebagai masyarakat yang hidup secara sederhana pada sector agraris, mempunyai ikatan sosial, adat dan tradisi yang kuat, bersahaja, serta tingkat pendidikan yang rendah (Juliantara, 2005: 18).

Berdasarkan Peraturan Pemerintah No 72 Tahun 2005, Desa atau yang disebut dengan nama lain selanjutnya disebut desa, adalah kesatuan masyarakat hukum yang memiliki batas-batas wilayah yang berwenang untuk mengatur dan mengurus kepentingan masyarakat setempat, berdasarkan asal-usul dan adat-istiadat setempat yang diakui dan dihormati dalam sistem Pemerintahan Negara Kesatuan Republik Indonesia dan berada di Kabupaten/Kota, dalam pasal 2 ayat (1) dikatakan bahwa desa dibentuk atas prakarsa masyarakat dengan memperhatikan asal-usul desa dan kondisi sosial budaya masyarakat setempat. Tugas pemerintahan adalah untuk melayani dan mengatur masyarakat. Tugas pelayanan lebih menekankan upaya mendahulukan kepentingan umum, mempermudah urusan publik dan memberikan kepuasan kepada publik, sedangkan tugas mengatur lebih menekankan kekuasaan power yang melekat pada posisi jabatan birokrasi. Menurut Rasyid dalam Maulana (2014:1), ada tiga tugas pokok pemerintah, yaitu:

1. Pelayanan (service), sebagai provider jasa publik yang baik diprivatisasikan dan layanan civil termasuk layanan birokrasi. Pemerintah yang bertindak sebagai mana seorang pelayan yang melayani konsumennya, dalam hal ini masyarakatnya haruslah dengan tulus dan ikhlas.

2. Pemberdayaan (empowerment), sebagai penyelenggara program pemberdayaan masyarakat. Pemerintah dalam otonomi daerah sekarang ini memiliki interaksi dengan masyarakat yang sudah lebih dekat, dimana pemerintah sekarang haruslah lebih aktif dalam melibatkan masyarakat dalam sebuah manajemen, baik dalam manajemen yang melakukan pemberdayaan kepada masyarakat.
3. Pembangunan (development), sebagai penyelenggara pembangunan untuk menciptakan kesejahteraan sosial masyarakat. Dalam melakukan sebuah pembangunan, pemerintah haruslah mempertimbangkan beberapa hal yang signifikan guna pembangunan tersebut benar-benar bermanfaat dan untuk kepentingan orang banyak. Pembangunan sangatlah perlu dalam sebuah pelayanan dan pemberdayaan masyarakat. Sehingga pada intinya tugas pemerintah tersebut di atas saling memengaruhi satu sama lain.

Pada dasarnya pembangunan pedesaan bertujuan dan diarahkan untuk mewujudkan masyarakat adil dan makmur materil dan spiritual berdasarkan pancasila di dalam wadah Negara Kesatuan Republik Indonesia yang merdeka, bersatu dan berdaulat dalam suasana perikehidupan bangsa yang aman, tenteram dan dinamis. Secara rinci Djiwandono (Nurman, 2015:242) menjelaskan tujuan pembangunan desa meliputi:

1. Tujuan ekonomis, yaitu meningkatkan produktiviti di daerah pedesaan dalam rangka mengurangi kemiskinan di daerah pedesaan.

2. Tujuan sosial, ke arah pemerataan kesejahteraan penduduk desa, dan budaya dalam arti peningkatan kualiti hidup pada umumnya dari masyarakat pedesaan.

3. Tujuan demografis, ke arah meningkatkan potensi sumber daya alam, dan tingkat kepadatan penduduk per-kapita.

4. Tujuan politis, dalam arti menumbuh dan mengembangkan partisipasi masyarakat desa secara maksimal dalam menunjang usaha-usaha pembangunan serta dalam memanfaatkan dan mengembangkan hasil-hasil pembangunan.

\section{B. METODE PENELITIAN}

Desain penelitian yang digunakan adalah deskriptif dengan menggunakan pendekatan Kuantitatif.

Populasi ini berjumlah 1.231 KK (LPPD Desa Bulucenrana Tahun 2018). Dari 1.231 jumlah populasi, maka jumlah sampel adalah $92 \mathrm{KK}$ menggunakan rumus Slovin. Teknik penarikan sampel yang digunakan adalah Purpossive Sampling, yang dijadikan sebagai Informan yaitu Badan Perwakilan Desa di 
Desa Bulucenrana Kecamatan Pitu Riawa Kabupaten Sidenreng Rappang.

Teknik pengumpulan data terdiri dari observasi, wawancara, penelitian pustaka (library research) dan kuesioner. Teknik analisis data dalam penelitian kuantitatif menggunakan statistic dengan bantuan SPSS v.16. dengan menggunakan regresi linear sederhana.

\section{HASIL DAN PEMBAHASAN}

Desa Bulucenrana terbagi menjadi 6 Dusun, yaitu: Dusun I Bulucenrana, Dusun II Pujo, Dusun III Bottolita, Dusun IV Bulucenrana, Dusun $V$ Bulucenrana, Dusun VI Cibokka. Sebelah utara berbatasan dengan Desa Botto, sebelah selatan berbatasan dengan Desa Dongi, sebelah barat berbatasan dengan Desa Anabannae, dan sebelah timur berbatasan dengan Desa Bola Bulu.

Hasil penelitian pada variabel independen yaitu partisipasi perempuan dengan rata-rata persentase $56 \%$ kategori kurang baik terdiri dari indikator partisipasi uang $59 \%$ kategori kurang baik, partisipasi harta benda $59 \%$ kategori kurang baik, partisipasi tenaga $56 \%$ kategori kurang baik, partisipasi keterampilan $49 \%$ kategori kurang baik, partisipasi buah pikiran 58\% kategori kurang baik, partisipasi sosial 57\% kategori kurang baik. Variabel dependen yaitu penyelenggaraan Pemerintahan Desa dengan rata-rata persentase $54 \%$ kategori kurang baik terdiri dari pelayanan (service) $61 \%$ kategori baik, pemberdayaan (empowerment) $50 \%$ kategori kurang baik, pembangunan (development) 52\% kategori kurang baik. Faktor-faktor yang Memengaruhi Partisipasi Perempuan dalam Penyelenggaraan Pemerintahan Desa Bulucenrana terdiri dari faktor aspek ekonomi $74 \%$ kategori baik, aspek sosial budaya $76 \%$ kategori baik, aspek geografi wilayah 74\% kategori baik. Dengan bantuan SPSS v.16 menggunakan rumus regresi linear sederhana maka diperoleh $\mathrm{R}^{2}$ aspek ekonomi $0.22 \times 100=22 \%, R^{2}$ aspek sosial budaya $0.41 \times 100=41 \%$, aspek geografi wilayah $0.81 \times 100=81 \%$.

\section{KESIMPULAN}

Partisipasi perempuan 56\% kurang baik dan penyelenggaraan Pemerintahan Desa $54 \%$ kurang baik. Aspek ekonomi 22\%, aspek sosial budaya $41 \%$, aspek geografi wilayah $81 \%$ memengaruhi tingkat partisipasi perempuan dalam penyelenggaraan Pemerintahan Desa Bulucenrana.

\section{E. REFERENSI}

Ahmad, Jamaluddin. 2015. Metode Penelitian Admistrasi Publik. Gava Media. Yogyakarta.

Dwiningrum, S.I.A. 2013. Desentralisasi dan Partisipasi Masyarakat dalam Pendidikan. Pustaka Pelajar. Yogyakarta.

Juliantara, Dadang. 2005. Transformasi Pelayanan Publik. PEMBARUAN. Yogyakarta.

Maulana, Rachmat. 2014. Fungsi-Fungsi Pemerintahan. Article. STIE DwiMulya.

Nasir, Moh. 2005. Metode Penelitian. Ghalia Indonesia. Jakarta.

Nurcholis, Hanif. 2011. Pertumbuhan dan Penyelenggaraan Pemerintahan Desa. Erlangga. Jakarta.

Nurman. 2015. Strategi Pembangunan Daerah. RajaGrafindo Persada. Jakarta.

Remiswal. 2013. Menggugah Partisipasi Gender di Lingkungan Komunitas Lokal. Graha IImu. Yogyakarta.

Sumpeno, Wahjudin. 2004. Perencanaan Desa Terpadu. READ. Banda Aceh.

Wasistiono, Sadu dan Tahir, Irwan. 2006. Prospek Pengembangan Desa. Fokus Media. Bandung.

Widjaja, HAW. 2003. Pemerintahan Desa/Marga. RajaGrafindo Persada. Jakarta.

Dokumen-dokumen :

Instruksi Menteri Dalam Negeri RI Nomor 11 Tahun 1972 tentang Pelaksanaan Klasifikasi dan Tipologi Desa.

Instruksi Presiden No 9/2000 tentang Pengarusutamaan gender.

Intruksi Presiden No 3/2010 tentang Pengarusutamaan gender.

Kementerian Perencanaan Pembangunan atau Badan Perencanaan Pembangunan Nasional bersama dengan Kementerian Pemberdayaan Perempuan dan Perlindungan Anak Nomor 75844, Kertas kebijakan 1, Pengarusutamaan Gender.

Laporan Pertanggung Jawaban Desa Bulu Cenrana, Desember 2018. 
Peraturan Pemerintah RI (PP) Nomor 76/2001 tentang Pedoman Umum Pengaturan mengenai Desa.

Peraturan Pemerintah No 72 Tahun 2005 tentang Desa.

Undang-Undang Nomor 32 Tahun 2004 tentang Desa.

Undang-Undang Nomor 6 Tahun 2014 tentang Pemerintahan Desa.

Undang-Undang Nomor 23 Tahun 2014 tentang Pemerintahan Daerah.

Surat Menteri dalam Negeri Nomor: 140/640SJ tanggal 22 maret 2005 tentang Pedoman Alokasi Dana Desa.

Jurnal:

Kogoya, Teraik dkk. 2015. Partisipasi Masyarakat terhadap Pembangunan Infrastruktur Jalan Desa di Kabupaten Lanny JayaPapua. Jurnal Berkala IImiah Efisiensi Volume 15 No.2.

Rini, Rinawati. 2004. Partisipasi Wanita dalam Pembangunan, Kajian Gender mengenai Partisipasi Wanita dalam Pembangunan Partisipatif melalui Pemberdayaan Masyarakat. Volume XX No.3 Juli-September. UNISBA.

Sulistiowati, dkk. 2012. Evaluasi Kebijakan Responsif Gender Bidang Pendidikan di Provinsi Lampung. E-Journal, 211-226.

Skripsi-skripsi:

Awang, Azam. 2010. Implementasi Pemberdayaan Pemerintah Desa (Studi Kajian Pemberdayaan Berdasarkan Kearifan Lokal di Kabupaten Lingga Provinsi Kepulauan Riau). Pustaka Pelajar. Yogyakarta.

Hirdayanti, Sakti. 2018. Partisipasi Masyarakat dalam Menunjang Pelaksanaan Musyawarah Perencanaan Pembangunan Desa di Desa Timoreng Panua Kecamatan Panca Rijang Kabupaten Sidenreng Rappang. STISIP M Rappang.

Oktavia, Mia Arta. 2018. Kepemimpinan Kepala Desa dalam Meningkatkan Partisipasi Perempuan pada Pemerintahan Desa (Studi pada Kampung Jaya Sakti Kecamatan Anak Tuha
Kabupaten Lampung Tengah). Universitas Lampung. Bandar Lampung. 